\title{
CARBON EMISSIONS DISCLOSURE AND FIRM VALUE: DOES ENVIRONMENTAL PERFORMANCE MODERATE THIS RELATIONSHIP?
}

\author{
Mohammad Hardiyansah ${ }^{a}$ \\ Aisa Tri Agustini ${ }^{b}$ \\ ${ }^{a, b}$ Accounting Department, Faculty of Economics and Business, University of Jember \\ Email: nadiyansah.97@gmail.com ${ }^{a}$; aisa.agustini@gmail.com ${ }^{b}$
}

ARTICLE HISTORY
Received:
10 January 2021
Revised:
12 April 2021
Accepted:
31 May 2021
Online available:
30 June 2021
Keywords:
Carbon Emissions
Disclosure,
Firm Value,
Environmental
Performance,
Indonesian Sharia Stock
Index,
Moderated Regression
Analysis.
*Correspondence:
Name:
Mohammad Hardiyansah
E-mail:
nadiyansah.97@gmail.com

\begin{abstract}
The objectives of this research is to examine the role of environmental performance in the relation between carbon emissions disclosure and firm value. A measurement tool using content analysis method to measure carbon emissions disclosure that adopts a checklist from the Carbon Disclosure Project (CDP). Firm value is proxies with Tobin's $Q$, while environmental performance is assessed based on the results of the environmental management performance appraisal program (PROPER). Sample of this study using 34 companies that listed on the Indonesian Sharia Stock Index (ISSI) from 2014 to 2019. Moderated regression analysis (MRA) is used to test the hypothesis. The results indicate the carbon emissions disclosure has a positive and significant effect on firm value. This research also found that there is an evidence that environmental performance can strengthen the relation of carbon emissions disclosure to firm value, due to the company's efforts by participating in the PROPER program is a form of corporate responsibility in an effort to reduce the impact of environmental damage arising from the company's operational activities which have been responded positively by investors.
\end{abstract}

\section{INTRODUCTION}

Firm value can be interpreted as an investor's view of the success of corporate governance related to the level of profitability and the company's stock price. Firm value can be perceived as having a high value if the stock price is also high and profitability, which is one of the benchmarks for investors to invest. At present the survival of a company is not only determined by the profitability of the company as it is generally, but also determined by the company's ability to collaborate economic performance, social justice, and responsibility for environmental sustainability (Juniarti \& Sentosa, 2009). 
So far the business world seems to have only focused on gaining profit, but now the company is trying to build the impression that the company is not only focused on profit but also will be responsible for the community and the surrounding environment. This change in orientation is due to pressure from many parties so that companies can respond to the issue of global climate change that is so extreme because of the increase in the amount of greenhouse gas emissions originating from the industrial activities of world companies. According to the Kyoto Protocol which is classified as greenhouse gas emissions namely: Carbon Dioxide (CO2), Sulfur hexafluoride (SF6), Nitrous oxide ( $\left.\mathrm{N}_{2} \mathrm{O}\right)$, Methane ( $\mathrm{CH} 4)$, Fluorinated gases (PFCS), and Hydrofluorocarbons (HFCS) (Irwhantoko \& Basuki, 2016). This research focused on Carbon Dioxide (CO2) emissions only. The following is a diagram of 2018 greenhouse gas emissions according to data released by the US Environmental Protection Agency (US EPA).

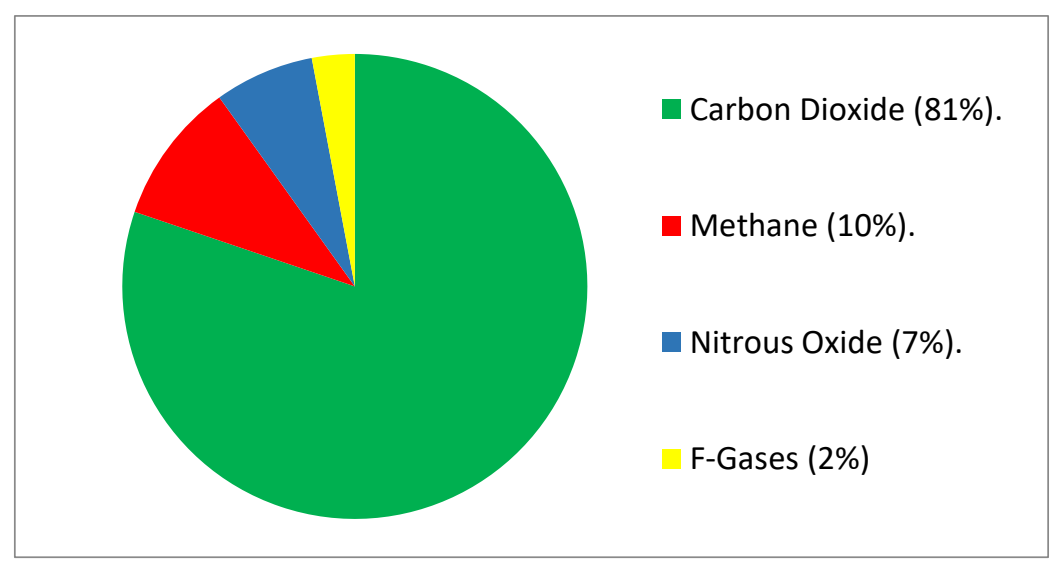

Figure 1. Global Greenhouse Gas Emissions by Gas in 2018

Source: United States Environmental Protection Agency (2018)

Carbon emissions disclosure is a manifestation of the company's responsibility for the carbon emissions it produces, in Indonesia this is in line with the existence of UU Number 40 of 2007 about Limited Liability Company (Ltd), where initially carbon emissions disclosure is only limited to choice, but now it can be said that this carbon emissions disclosure is a company must be carried out in maintaining the continuity and balance of nature. Carbon emissions disclosure includes the disclosure of the total energy consumed and the quantification of the use of renewable energy which will provide greater benefits to the sustainability of environmental ecosystems and ensure the continuity of life of the current generation and the next generation. Kelvin et al. (2017) state that disclosure of the sources types of carbon emissions owned by companies such as equipment, vehicles or machinery will also provide benefits to management in determining a maximum asset management strategy. Delmas and NairnBirch (2011) show that increasing disclosure of carbon emissions has a positive 
relationship with the company's operational performance. However, Gallego-Alvarez et al. (2015) show that there is no evidence that disclosure of $\mathrm{CO}_{2}$ emissions has relationship with operational performance as measured by ROA. The operational performance affected due to the disclosure of carbon emissions is closely related to the value of the company. Höbarth (2006) shows that ROA has a positive and significant effect on firm value as measured by Tobin's $Q$ ratio.

The SRI-HAYATI index, a joint index between the Indonesia Stock Exchange (IDX) and the Indonesian Biodiversity Foundation (HAYATI), placed Twenty-five companies to the SRI-HAYATI index in 2013. The twenty-five companies were stated to have a share value of $10 \%$ higher than other companies listed on IDX in 2013 . This is due to environmental concerns, especially the reduction of carbon emissions by companies that follow the index as measured by sustainability reports (Hadi, 2013). This can indicate that the disclosure of carbon emissions can be a special attraction for investors to companies that make disclosures of carbon emissions, this is based on an increase in the price of shares of companies that make carbon emission disclosures.

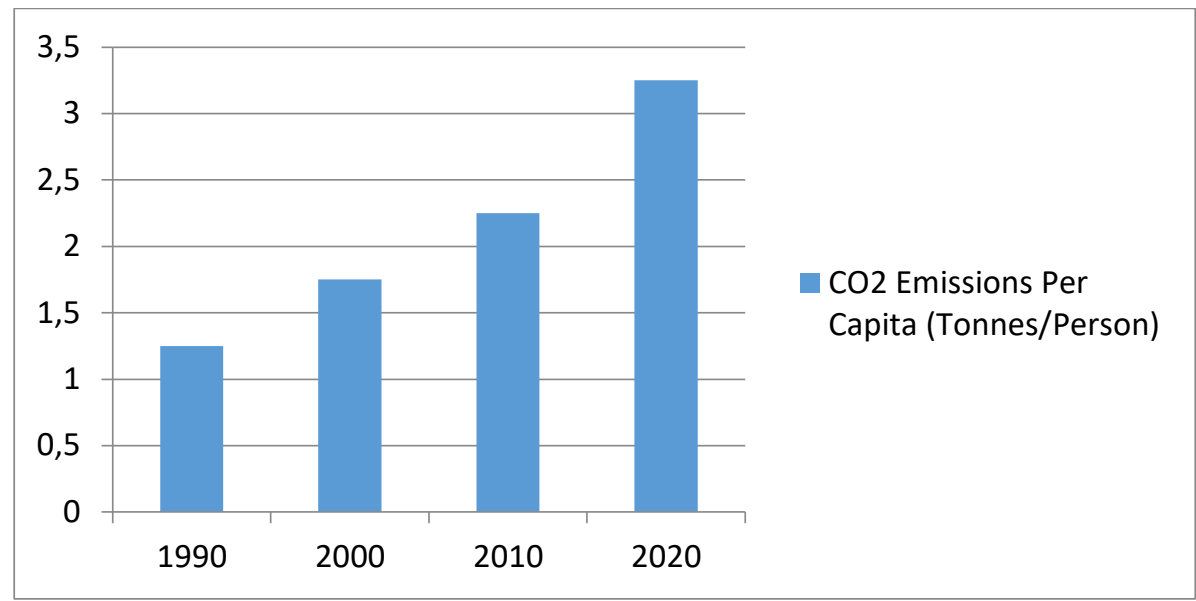

Figure 2. Carbon Emissions From Energy Use In Indonesia Using The IPCC Method Source: Purwanto et al. (2006)

Indonesia's condition is increasingly worrying because the amount of carbon emissions produced continues to increase from year to year. This makes the public put pressure on the company which makes companies worry about environmental issues and thus discloses carbon emissions (Peng et al., 2014). Companies that carry out carbon disclosure will make it easier for stakeholders to make decisions about the state of the company's carbon emission performance, pressure companies to reduce carbon emissions, contribute to public debate on climate change policies and regulations (Ennis et al., 2012). The Indonesian government through the Ministry of Environment issued a Ministerial Regulation Number 05, 2011, regarding PROPER to assess corporate responsibility in business or company activities in controlling environmental damage and 
environmental polution, and assessing management of waste dangerous and toxic produced by the company.

This situation makes it appropriate for the company not only to focus on pursuing profit but also to provide responsibility for the impact of environmental damage caused by its operational activities. One form of accountability in the perspective of Islamic economics must be in accordance with sharia principles, so the concept of Islamic Social Reporting (ISR) emerged. ISR is a development of a social reporting standard that focuses on people's expectations of the role of companies in the economy as well as in a spiritual perspective, so that ISR also focuses on social balance both towards the environment, minority rights, and society (Fitria \& Hartanti, 2010). Hanifa (2002) explains five disclosure concepts in the ISR index, namely funding and investment, products and services, employees, society, and environment. Therefore, the company's performance in achieving a balance between each component of the disclosure must be done. Environmental performance or environmental performance must be part of the company's focus on its accountability. This is because Allah SWT provides the earth and all of its contents, including natural resources and the environment, for humans to manage without destroying it.

Anggraeni (2015) stated that highest ranking companies performance in the PROPER index can strengthen the relationship between social and environmental responsibility towards the firm value. This is because the gold color indicates that the company has managed its environment properly as required, and the company has made continuous development efforts towards the community. Environmental performance is an assessment of the relationship between a company and its environment which includes environmental impacts on the use of resources consumed, environmental impacts on operational processes, environmental impacts on products or services produced by the company, and environmental recovery and processing of products that meet requirements law. Therefore, companies that have good environmental performance will get a good reputation from their stakeholders. Environmental performance assessed by PROPER is predicted to strengthen the relationship between carbon emissions disclosure to firm value. The prediction is related to signaling theory, which clearly states that good environmental performance is good news for investors to dare to invest their funds in companies that disclose carbon emissions and obtain good environmental performance ratings, so that the signal can increase the value of the company in the eyes of investors.

Carbon emissions disclosure is an issue that is currently developing rapidly and widely in various countries due to the extreme impacts of climate change and threatening the survival of humans and companies, including Indonesia. Particularly, in 
Indonesia, for the disclosure of carbon emission originating, it is not so many companies that disclose carbon emissions. In the midst of an environment that is of public concern because of its enormous impact, disclosure of carbon emissions can be the responsibility of the company to the public to maintain the company's sustainability so that it can get the trust of the public that the company also tries to care and respond to environmental problems.

In addition to carbon emissions disclosure, companies are also required to have good environmental performance that reflects the company's real efforts to reduce carbon emissions produced as well as other efforts aimed at environmental sustainability, to assess the company's environmental performance, there must be an independent external party to assess this. Government is one of the parties that can assess, supervise, direct, or impose sanctions if a company damages the environment. The Indonesian government through the PROPER program aims to invite entities to work together in terms of reducing the effects of environmental damage due to waste generated from company operations.

This is certainly interesting to conduct research because in addition to the disclosure of voluntary carbon emissions by companies with the aim of giving a signal to the public to gain public legitimacy as a company that cares about the environment, of course this must also be accompanied by the company's concrete efforts to suppress the resulting carbon emissions. The company's efforts are expected to get legitimacy from the community, this legitimacy will make the company participate in the PROPER program where the results of the assessment can become a public reference whether companies that disclose carbon emissions have good environmental performance so that the public gives legitimacy that the company has a good image that will attract investors. to invest.

The population in this research is the entire company that was listed on the Indonesian Sharia Stock Index (ISSI) for six years, 2014-2019. The reason the researchers chose the research period from 2014-2019, is because the second period of the Kyoto Protocol began on January 1, 2013 and the countries involved in this second period will report on efforts to reduce carbon emissions in 2014, Indonesia ratified the second period of the Kyoto Protocol on September 30, 2014. The World Meteorological Organization (WMO) shows a report stating that 2019 was the hottest year on record. WMO also claims that the world has produced 37 billion metric tons of emissions in 2019, up 0.6 percent from 2018. Therefore, researchers took a research period from 2014 to 2019 to assess whether efforts to disclose carbon emissions, and efforts to improve the company's environmental performance by participating in the PROPER program, received a positive response from investors when public pressure was very high due to an increase in the amount of carbon emissions on earth. 
This research is interesting and different from previous studies because in this study, besides including carbon emissions disclosure as the dependent variable and firm value as the independent variable. This study also includes a moderating variable that will later affect the relationship between the dependent and independent variables. The moderating variable used in this study was environmental performance. Therefore, apart from examining the effect of carbon emissions disclosure on firm value, this study will also test whether environmental performance can strengthen the relationship between carbon emissions disclosure and firm value. This study also uses several control variables that researcher controls so that the independent and dependent variables cannot be influenced by external factors that are not studied. The control variables used in this study are profitability, company size, and leverage. Another thing that distinguishes this research is that this research uses all companies registered with the Indonesian Sharia Stock Index (ISSI) from 2014 to 2019 that meet the criteria as research objects.

\section{LITERATURE REVIEW}

\section{Legitimacy Theory}

Gray et al. (1995), basic legitimacy theory is a social contract whereby all business entities, including companies that live side by side with the community environment, have a social contract that is stated directly or indirectly. Disclosure of carbon emissions has reasons to gain legitimacy from stakeholders, avoiding corporate threats resulting from greenhouse gas profits such as increased operating costs, reduced demand, reputation risk, due process, fines and penalties (Berthelot \& Robert, 2011). Therefore, according to this theory, the disclosure of carbon emissions and environmental performance is part of the company's efforts in responding to the pressures of the community on their existence, so that the company can obtain legitimacy from the community and other stakeholders.

\section{Signaling Theory}

Financial and non-financial information presented by companies that can be trusted in truth can make the company obtain indirect benefits. Deegan and Unerman (2006) this makes disclosure of information related to environmental performance will provide positive information signals for stakeholders, this is because companies that voluntarily disclose carbon emissions and environmental performance have provided information needed by stakeholders. 


\section{Triple Bottom Line Theory}

This theory was introduced by (Elkington, 1997), in which he revealed that the size of the company's success is not only seen from how good the company's financial performance is, but also from a broad economic side, namely also from the environmental and community aspects in which the company operates. This theory uses three elements of performance measurement namely Economic, Environmental, and Social (EES), or better known as profit, planet, and people (Triple P). This theory is the basis for researchers to see the relationship or workings of the carbon emissions disclosure variables that affect the firm value and environmental performance variables. This is because carbon emissions disclosure carried out by companies and companies also striving to improve their environmental performance is a form of corporate responsibility in environmental sustainability (planet), this form of responsibility certainly has a goal so that the company has a good image that is perceived by the public and obtains legitimacy from the public that companies care about the environment (people), with a good image and legitimacy from the public, this will attract investors to invest in the company and the company's products, both services and goods, will be accepted by the public (profit).

\section{Carbon Emissions Disclosure}

Information related to carbon emissions in Indonesia is widely presented in the company's environmental accountability report without considering monetary information related to costs and obtaining financing for the company's efforts to reduce carbon emissions. In Indonesia the disclosure of carbon emissions is presented as a form voluntary disclosures used for internal and external decision making (Andrew \& Cortese, 2011). Statement of Financial Accounting Standards (PSAK) No. 1 in paragraph 9 stated that: "companies can also provide additional reports such as on the environment and value added reports, especially for industrial sectors where environmental factors play an important role".

\section{Firm Value}

Firm value can be perceived as having a high value if the stock is also high, companies that have high corporate value can influence investors in the stock market. The influence is that investors will have the view that the company is not only good at its current performance, but the prospects for future company performance can also be considered good. 


\section{Environmental Performance}

Environmental performance is a measure of a company's performance to be able to produce good and sustainable environmental conditions. In Indonesia, the implementation of the company's environmental performance is carried out through a company performance rating appraisal program (PROPER), which is an assessment instrument issued by the Ministry of Environment to carry out assessments and rating of companies in carrying out their environmental performance.

\section{Environmental Themes in the ISR Index}

The concepts that form the basis of this theme are mizan, i'tidal, khilafah, and akhirah. This concept focuses on simplicity, balance, and the responsibility of the earth's inhabitants in maintaining environmental conditions. Islam teaches each of its followers to always protect, preserve and preserve the earth. The disclosures that are informed in the theme of the environment are related to environmental conservation, reduction of environmental pollution, education related to the environment, awards in the environmental field, and environmental management systems (Othman et al., 2009). Allah SWT has conveyed this in His words on Surah Ar-Rum verse 41, "It appears that the damage on land and at sea was caused by the actions of human hands, so that Allah will feel for them a part of (the result of) their actions, so that they will return (to the right path).

\section{Hypothesis}

Firm value is a reflection of the assessment of investors to what extent the success of the company manages its company, whether it has been managed properly or not. Investors assume that the company's survival is not only influenced by its high profitability, but also determined by a balanced combination of economic performance, social justice focus, and corporate responsibility for environmental sustainability (Juniarti \& Sentosa, 2009). Based on legitimacy theory, the company's motivation in carrying out carbon emissions disclosure is to gain legitimacy from its stakeholders to support the company's operational activities. With this legitimacy, investors will not hesitate to invest in companies. Companies will also avoid lawsuits because they take care of their environment, and the public will not hesitate to buy products and even become customers because the company cares and cares for the environment. This is also in line with Triple bottom line's theory which says that companies must collaborate between the three basic pillars of profit, environment (planet), and society (people) in their business practices.

Published by University of Airlangga.

This is an open access article under the CC BY license (https://creativecommons.org/licenses/by-nc-sa/4.0/) 
Anggraeni (2015) in his research shows that the disclosure of greenhouse gas emissions has a positive and significant effect on firm value. Based on stakeholder theory, the company is not an entity that stands and operates for itself but also must provide benefits to its stakeholders which include investors, consumers, government, society, and other parties. Auliya (2018) shows that corporate social responsibility and environmental performance have a positive and significant effect on firm value. According to the legitimacy theory, the company's motivation in carbon emissions disclosure is to get legitimacy from stakeholders, so that it will support the company's operational activities. With this legitimacy, investors will not hesitate to invest heavily in companies that care about the environment by revealing carbon emissions produced by the company.

H1: Carbon emissions disclosure has a positive effects on firm values.

Environmental performance can be a reinforcement of the influence of carbon emissions disclosure on firm value, this is based on signaling theory which explains that the signals from information disclosed by the company will then be captured by investors to be considered in making investment decisions. Environmental performance reflects the extent to which the company cares about the environment affected by its operations. In reality companies will tend to disclose information that is good news only and withhold information related to the environment they do not care about, so that it will adversely affect the company's reputation. This is because the company considers that bad news can reduce investor confidence in the company, so that it will have an impact on the withdrawal of funds invested. Auliya (2018) shows that environmental performance assessed by PROPER has a positive and significant influence on the value of the company that is proxies with Tobin's $Q$.

H2: Environmental performance can moderate the relationship between carbon emissions disclosure and firm values.

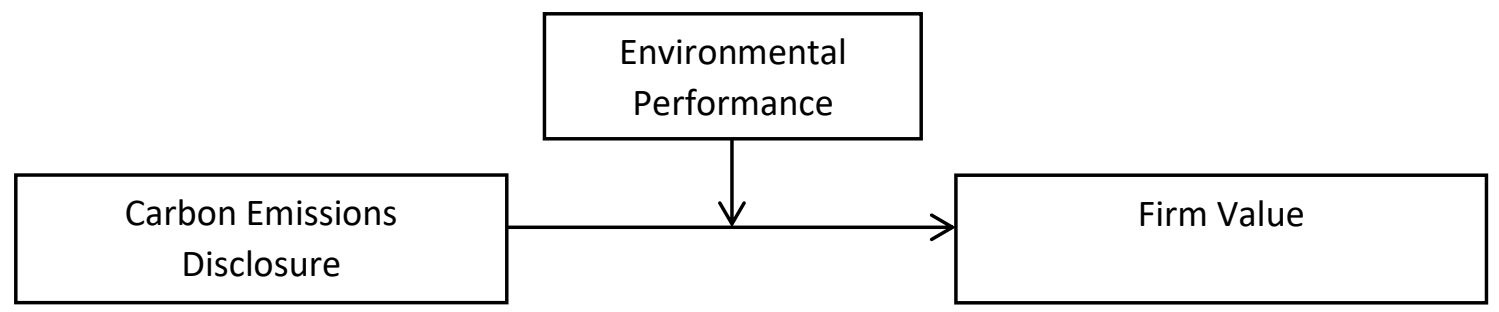

Figure 3. Moderating Effect Of Environmental Performance 


\section{RESEARCH METHODS}

\section{Population and Samples}

The population in this research is the entire company that was listed on the Indonesian Sharia Stock Index (ISSI) for six years, 2014-2019. To get a representative sample, purposive sampling technique was used. Samples taken must meet the sample criteria set by researchers to support problem solving in research. The criteria for sampling are as follows:

1. Companies listed on ISSI starting in January 2014 until the end December 2019.

2. The company publishes a complete annual report or sustainability report for the period 2014-2019 and the company must at least disclose one item of carbon emissions disclosure.

3. The company registered every year in following the PROPER assessment from 2014-2019.

\section{Types and Data Sources}

The type of data used is secondary data sourced from annual reports, sustainability reports, and ranking data in PROPER. The data can be downloaded on the company's official website, www.idx.co.id and www.proper.menlh.go.id.

\section{Research Variables}

Independent Variables

Carbon Emissions Disclosure (CED) is the independent variable used in this research, this variable is measured using the content analysis method. The measurement item for disclosure of carbon emissions is to use an index adopted from the research of Choi et al. (2013); Saka and Oshika (2014). This index was developed by Choi et al. (2013) which consists of five assessment groups related to climate change and carbon emissions, namely climate change, greenhouse gas emissions, energy consumption, greenhouse gas reduction and costs, and carbon emission accountability. For the calculation of the carbon emissions disclosure index, the steps are as follows:

1. There are 18 items of disclosure, give a score of 1 for each item disclosure. Maximum score is 18 and minimum score is 1.

2. The result of the total score of the disclosure is further divided by the total disclosure items ie 18. Following the formula:

$\frac{\text { Total score of CED }}{\text { Total disclosure item }} \times 100 \% \ldots$




\section{Dependent Variable}

The variable intended in this research is firm value (FV). Firm value is proxies by Tobin's $Q$. Tobin's $Q$ focuses on some of the company's current values relative to the amount of costs needed to replace them now. following the formula (Höbarth, 2006):

((Year-end closing price * Total shares outstanding) + Total liability)

(Total assets + Total liability)

Moderating Variable

The moderating variable in this research is Environmental Performance (EP) as measured by rating in PROPER. The PROPER Rating System includes five colors, namely:

Table 1

Value of Environmental Performance

\begin{tabular}{ccc}
\hline Ranking & Information & Value \\
\hline Gold & Very-Very Good & 5 \\
Green & Very Good & 4 \\
Blue & Well & 3 \\
Red & Bad & 2 \\
Black & Very Bad & 1 \\
\hline
\end{tabular}

Source: Rahma (2010)

\section{Control Variables}

1. Profitability (Pro), measured using ROA because ROA reflects the efficiency of the company.

2. Institutional Ownership (IO), high institutional ownership reflects a large share of investment owned by other institutions.

3. Leverage (Lev), the higher level of company leverage, the greater the responsibility of the company to the creditor. Leverage is proxies by Debt Equity Ratio.

\section{Moderated Regression Analysis (MRA)}

The relationship between the independent variable and the dependent variable has the possibility to be relied on by other variables, one of which is the moderating variable. The moderating variable can assess or weaken the relationship between the independent variable and the dependent variable, so it uses the MRA method to test the hypothesis. This study examines the effect of carbon emission disclosure on firm value, as well as testing environmental performance as a moderating variable that can affect the relationship between carbon emissions disclosure and firm value. MRA is a special application of multiple linear regression where the regression equation contains an element of interaction (multiplication of two or more independent variables with 
moderating variables), so it is suitable to be used to test the hypothesis in this study. The following is the MRA used:

$$
\mathrm{FV}=\alpha+\beta 1 \text { CED1 }+\beta 2 \text { EP } 2+\beta 3 \text { CED1 } * \text { EP2 }+\beta 4 \text { Pro }+\beta 610+\beta 7 \text { Lev }+ \text { e } \ldots . .(3)
$$

The MRA model used in this study can provide conclusions on the results of teshe first and second hypotheses which will be useful for assessing whether environmental performance as a moderating variable falls into what moderation category.

\section{RESULTS AND ANALYSIS}

\section{Variables Descriptive Analysis}

This section will describe the results of the descriptive analysis of all the research variables used which consist of the dependent variable, the independent variable, the moderating variable, and the control variable.

Table 2

Descriptive Statistics

\begin{tabular}{lrrrr}
\hline & \multicolumn{1}{c}{ Min. } & \multicolumn{1}{c}{ Max. } & \multicolumn{1}{c}{ Mean } & Std. Deviation \\
\hline CED & 0.11 & 0.89 & 0.53 & 0.29 \\
FV & 0.41 & 11.01 & 1.06 & 3.54 \\
EP & 2.40 & 5.00 & 3.30 & 0.47 \\
Pro & $(0.18)$ & 0.38 & 0.05 & 0.00 \\
Lev & $(2.10)$ & 11.27 & 2.40 & 1.28 \\
IO & 0.34 & 0.97 & 0.60 & 0.59 \\
\hline
\end{tabular}

Source: SPSS Data Processed

The independent variable in this study is Carbon Emissions Disclosure (CED) which is measured using content analysis in the form of a check list of 18 disclosure items adopted from the research of (Choi et al., 2013). From the table above the CED variable has an average value of 0.53 or the average disclosure of 9 CED items. The dependent variable in this study is firm value (FV) which is measured using Tobin's Q. From the table above it can be seen that the firm value variable has an average value of 1.06. The moderating variable is environmental performance (EP) which is measured by the color ranking in the PROPER program, namely gold, green, blue, red black, from the table above the EP variable has an average value of 3.30 which means average the company is ranked blue in PROPER. 


\section{Overall Significance of Regression Test Samples (F Statistic Test)}

To test whether all the independent variables and control variables in this model affect simultaneously or as a whole on the dependent variable it can be seen from the results of simultaneous test results in regression analysis.

Table 3.

Simultaneous test results in regression analysis (F Test).

\begin{tabular}{cccl}
\hline The Regression Model & F & Sig. & Conclusion \\
\hline Multiple Regression Model & 27.100 & 0.000 & Ha Accepted \\
\hline
\end{tabular}

Source: SPSS Data Processed

The table above shows that simultaneously all determinants of firm value produce a significance value of 0.000 or less than 0.05 . Therefore, it can be concluded that all the determining factors, namely carbon emissions disclosure, environmental performance, profitability, leverage, and institutional ownership, can simultaneously influence firm value.

\section{Significant Individual Test Parameters (t Statistic Test)}

This study uses 34 samples of companies listed in the Indonesian Sharia Stock Index (ISSI) from 2014 to 2019 to partially test the effect of the dependent variable. The following are the results of testing the determinants of the dependent variable partially:

Table 4

\begin{tabular}{|c|c|c|c|c|c|}
\hline Variable & $\begin{array}{c}\text { Unstandardized } \\
\text { Coeficient } \\
(\beta)\end{array}$ & $\begin{array}{c}\text { Standardized } \\
\text { Coeficient } \\
(\beta)\end{array}$ & T-Stat & Sig. & Conclusion \\
\hline Firm Value & 17.718 & & 3.102 & 0.003 & \\
\hline Carbon Emission Disclosure & 0.173 & 0.189 & 2.375 & 0.021 & \\
\hline Environmental Performance & 0.086 & 0.017 & 0.281 & 0.133 & $\mathrm{H}_{1}$ \\
\hline Profitability & 0.398 & 0.660 & 11.945 & 0.000 & Accepted \\
\hline Institutional Ownership & 0.106 & 0.114 & 2.071 & 0.040 & \\
\hline Leverage & 0.312 & 0.147 & 2.652 & 0.009 & \\
\hline
\end{tabular}

Source: SPSS Data Processed

The statistical test shows evidence that hypothesis 1 is supported $(t=2.375$ with $p$-value $=0.021$ ). These results indicate that carbon emissions disclosure has a positive effect on firm value.

Based on the table above, it can be said that carbon emissions disclosure is a form of corporate concern in responding to pressure from various parties regarding environmental issues. It is also supported by the legitimacy theory which explains that there is a social contract between the company and the community, so that the motivation of companies to disclose carbon emissions is to gain legitimacy from the 
community. Such legitimacy will be the basis for investors to make decisions so that they want to invest their funds in companies that have gained good legitimacy from the community. Choi et al. (2013) revealed that there is a call from the environment, business, and politics so that companies can respond to threats caused by extreme global warming. Based on the theory of signals, carbon emissions disclosure carried out by companies can be seen by stakeholders as a form of concrete action by the company in efforts to reduce carbon emissions.

The results also support studies by Anggraeni (2015) and Auliya (2018) that showed a positive influence between carbon emissions disclosure on financial performance and firm value. The signaling theory also states that a good quality company will deliberately signal to the market, so the market is expected to differentiate good and bad quality companies. For the signal to be good, it should be captured and perceived good market and not easily imitated by companies that have poor quality. This is because investors assume that management has the capability to manage the environmental impact of its business operations (Griffin \& Sun, 2013). The triple bottom line theory explains that a company, in its business practices must align all of the three main pillars, namely profit (profit), environment (planet), and society (people), so that the company's survival is not only affected by its high profitability, but is also determined by a balanced combination of economic performance, focus of social justice, and corporate responsibility for environmental sustainability (Juniarti \& Sentosa, 2009). Therefore, investors will be attracted to companies that disclose carbon emissions because they show their concern for environmental sustainability. Environmental concern is one of the keys to a good company sustainability because it will make the company get support from its stakeholders and avoid conflicts with the community because this actually makes the company's image better in the eyes of the community, so that people will not hesitate to buy products or use the services of these companies.

These results conclude that the public gives a positive response to information on disclosure of carbon emissions by companies, so that stock prices increase and make the firm value even higher. The stock exchange index, as a result of the collaboration conducted by the Indonesia Stock Exchange and the Indonesian Biodiversity Foundation (SRI-KEHATI), placed twenty-five companies into the index in 2013. Twenty-five companies whose share value was declared $10 \%$ more expensive when compared to other companies, this shows that the companies care about the environment and conduct carbon emission disclosure, which is measured through disclosures in their sustainability reports (Hadi, 2013). This means that the disclosure of carbon emissions can attract investors, which can be seen from the high share price of companies implementing carbon emission disclosures. 
Table 5

Moderated Regression Analysis (MRA)

\begin{tabular}{lccccc}
\hline \multicolumn{1}{c}{ Variable } & $\begin{array}{c}\text { Unstandardized } \\
\text { Coeficient } \\
(\boldsymbol{\beta})\end{array}$ & $\begin{array}{c}\text { Standardized } \\
\text { Coeficient } \\
(\boldsymbol{\beta})\end{array}$ & T-Stat & Sig. & Conclusion \\
\hline Firm Value & 29.833 & & 3.652 & 0.001 & \\
Carbon Emission Disclosure ${ }^{*}$ & 0.326 & 0.429 & 3.206 & 0.003 & $\mathrm{H}_{2}$ \\
Environmental Performance & 0.398 & 0.661 & 12.046 & 0.000 & Accepted \\
Profitability & 0.106 & 0.114 & 2.078 & 0.039 & \\
Institutional Ownership & 0.312 & 0.146 & 2.658 & 0.009 & \\
Leverage & & & & & \\
\hline
\end{tabular}

Source: SPSS Data Processed

The statistical test shows that there is an evidence hypothesis 2 is supported $(t=$ 3.206 with $p$-value $=0.003$ ). These results indicate that environmental performance can moderate the relationship between carbon emissions disclosure and firm value.

Based on table above, environmental performance can strengthen the relationship with the effect of carbon emissions disclosure on company value. This result shows that PROPER ratings can be a guarantee whether the company has performed its environmental performance properly or not. Participating in the PROPER program is a form of corporate responsibility in an effort to reduce the impact of environmental damage arising from the company's operational activities. The results also support a studiy by Zafarina (2016) that explained that the environmental performance is positively related to the firm value (Tobin's $Q$ ). Based on legitimacy theory, companies that follow the assessment in PROPER will try to manage their environment well, so that they can get a good ranking in PROPER. With these ratings, the company can gain legitimacy from the government and society that the company has environmental performance well.

The results of this study are in line with the Triple Bottom Line Theory, where the company's environmental performance can strengthen the effect of disclosing carbon emissions on firm value. This is because environmental performance is a form of the company's efforts to reduce the impact of environmental damage, which means that the company also cares about the environment (planet). This effort is able to make the disclosure of carbon emissions that the company informs in its annual reports or company sustainability reports has appeal to the public to see whether the information submitted by the company is correct information, so that the results of environmental performance assessment through the PROPER program carried out by the Ministry of Environment is a guarantee of the information submitted by the company. The public will assume that those with good ratings in the PROPER program have good environmental performance, so that information about the company's carbon emission disclosures is responded to positively by the public (people). This makes the company have a good image in the public's eyes. This makes investors interested in investing and 
the company's products, both services and goods, will be accepted by the public (profit), so that the company's value will also increase.

This is also supported by signaling theory, where the rating in PROPER is appointed by investors as important information and it is good news for investors to make investment decisions. Environmental performance also makes the market respond positively to information about environmental performance, this is because PROPER can reflect overall environmental performance. PROPER is considered highly reliable information because environmental performance assessments by the Ministry of Environment become a guarantee that the company has carried out its environmental management properly or not. Therefore, it can be concluded that the market has responded positively to information on carbon emissions disclosure which is also supported by information on environmental performance ratings with PROPER, so that environmental performance further strengthens the effect of disclosure of carbon emissions in increasing the company's stock price in the stock market, and the increases can make the value of the company also higher. The results of this study are in line with the theory of legitimacy, where companies will try to get legitimacy or recognition from the community for the existence of the company. The company's efforts to gain legitimacy from the community are by aligning the economic goals the company seeks to achieve with its environmental and social objectives. So it can be said that if a company wants to increase its company value, it must be able to manage its environmental and social performance well.

\section{Moderation Group}

The following is the value of environmental performance variables to be able to draw conclusions about what moderation these variables are in:

Table 6.

Moderation Variable Group

\begin{tabular}{ccc}
\hline Variable & Influence/Significance & Variable \\
\hline Independent & $0.133>0.05$ (Non Significant) & Environmental Performance \\
Moderation & $0.003<0.05$ (Significant) & \\
\hline Independent : & Moderation Category & \\
Non Significant & Moderation : & Pure Moderation \\
Independent : & Significant & Quasi Moderation \\
Significant & Moderation : & \\
Independent : & Significant & Predictor Moderation \\
Significant & Moderation : & \\
Independent : & Non Significant & Homologizer Moderation \\
Non Significant & Moderation : &
\end{tabular}

Published by University of Airlangga.

This is an open access article under the CC BY license (https://creativecommons.org/licenses/by-nc-sa/4.0/) 
Source: SPSS Data Processed

Based on the results in Table 6, environmental performance (moderate variable) in this study falls into the pure moderation category, because when environmental performance is placed as an independent variable the results are not significant, but when it is placed as a moderate variable the results are significant. This shows that environmental performance as pure moderation moderates the relationship between carbon emission disclosure and firm value, where the environmental performance variable (moderator) interacts with the carbon emission disclosure variable (independent) without becoming an independent variable so that it is purely a moderator variable.

The results of this study can have theoretical, practical, and social implications. Theoretically, the implication of this research is to explain the relationship between several theories used when viewed from the theory of legitimacy clearly that companies that care about environmental issues have the main motivation to gain legitimacy from their stakeholders (investors). In accordance with the theory of the signal of concern for the environment expressed by the company, it is good news for investors and makes investors who are part of the stakeholders interested in investing in the company. Another theoretical implication is that this study enhances previous studies, especially by updating the research period, the methods used, and the addition of the control variables used in the study.

Practically, the results of the above research shows that carbon emissions disclosure can increase company value. So it can be concluded that concern for the environment at this time is not only a burden on the company, but also can be a corporate strategy in attracting investors. Therefore, the government should require companies to conduct carbon emissions disclosure, so this disclosure is not only voluntary but is a necessity. This research also shows that environmental performance (PROPER) can be a guarantee that the company has performed its environmental performance properly. From that, the government through the Ministry of Environment should rightly require companies listed on IDX to take part in the PROPER program which is currently only an option for companies, as evidenced by only 34 open companies participating in PROPER for six consecutive years (2014-2019).

Socially, the results of this study indicate that the public is increasingly responding to the issue of climate change because of its enormous impact. This response puts pressure on companies to care more about the environment by disclosing carbon emissions as well as real efforts made by companies for environmental sustainability. The results of this study can also provide an overview to the public so that they do not only look at the financial side of the company in deciding to invest, but also the company's environmental responsibility, if environmental responsibility with disclosure 
of carbon emissions and good environmental performance become one of the public consideration to invest in a company, it will make the company also focus on environmental aspects so that the impact of environmental damage caused by the company can gradually decrease.

\section{CONCLUSION}

Environmental preservation is a form of the responsibility of all humankind to Allah SWT inhabit and protect the earth. The earth that humans occupy is the creation of Him and belongs only to Allah SWT. Based on the result of the statistical test, it could be concluded that the carbon emissions disclosure has a positive and significant effect on firm value. The motivation of companies to disclose carbon emissions is to gain legitimacy from the community. Such legitimacy will be the basis for investors to make decisions so that they want to invest their funds in companies that have gained good legitimacy from the community. This research also show that environmental performance can moderate the relationship between carbon emissions disclosure and firm value. This results indicate that PROPER ratings can be a guarantee whether the company has performed its environmental performance properly or not. The results of this study indicate that companies are responsible for the environment by protecting their environment, because they are aware that everything that is carried out by the company will be held accountable before Allah SWT. Then this will increase the value of the company, because people will prefer to invest in shares of companies that care about the natural environment.

The results of this study can also provide suggestion that the Indonesian government through the Ministry of Environment should issue a rule that all companies listed on ISSI are required to take part in the PROPER program so that investors can find out how well the company is managing its environmental performance, with this policy, the research sample that measures environmental performance with the PROPER rating results will certainly be increasingly broad and representative. Further research is suggested to be assisted by several research assistants to determine the value of the information score for carbon emission disclosure as a comparison in order to minimize the possibility of subjectivity in the assessment.

Based on the research process, the researcher sees several limitations in this paper. First, the number of research samples is still relatively low because to assess environmental performance, it is only based on the PROPER ranking results during 20142019 so that only 34 companies were selected as samples. Second, there is the possibility of subjectivity in determining the carbon emission disclosure score on the disclosure index. This is because the determination of the score is only carried out by a 
researcher and not evaluated by other parties, which allows a difference in whether the sentence referred to in the annual report or the company's sustainability report is in accordance with the carbon emission disclosure indicator.

\section{ACKNOWLEDGMENT}

Alhamdulliah, I thank Allah SWT because of the blessings and gifts I have been able to complete this scientific article. Thanks to Mrs. Aisyah Tri Agustini as the mentor who always provided input for the writing of this article. Thanks to all of the Lecturers of S1 Accounting, Faculty of Economics and Business, University of Jember. Thanks to my both parents, friends, and those who have given their support. Hopefully, as a writer, in the future I can be even better at writing papers and not stop to make a paper that can be useful for the community and stakeholders.

\section{REFERENCES}

Andrew, J., \& Cortese, C. L. (2011). Carbon Disclosure: Comparability, the Carbon Disclosure Project and the Greenhouse Gas Protocol. Australian Accounting, Business, and Finance Journal, 5(4), 5-18. https://ro.uow.edu.au/aabfj/vol5/iss4/3/

Anggraeni, D. Y. (2015). Pengungkapan Emisi Gas Rumah Kaca, Kinerja Lingkungan, dan Nilai Perusahaan. Jurnal Akuntansi Dan Keuangan Indonesia, 12(2), 188-209. https://doi.org/10.21002/jaki.2015.11

Auliya, M. R. (2018). Pengaruh Kinerja Lingkungan terhadap Nilai Perusahaan dengan Corporate Social Responsibility sebagai Variabel Intervening. Universitas Negeri Yogyakarta.

Berthelot, S., \& Robert, A.-M. (2011). Climate Change Disclosure: An Examination of Canadian Oil and Gas Firms. Issues in Social and Environmental Accounting, 5(1), 106-123. https://doi.org/10.22164/isea.v5i2.61

Choi, B. B., Lee, D., \& Psaros, J. (2013). An Analysis of Australian Company Carbon Emission Disclosure. Pacific Accounting Review, 25(1), 58-79.

https://doi.org/10.1108/01140581311318968

Deegan, C., \& Unerman, J. (2006). Financial Accounting Theory. McGraw-Hill Education. Delmas, M. A., \& Nairn-Birch, N. S. (2011). Is The Tail Wagging The Dog? An Empirical Analysis of Corporate Carbon Footprints and Financial Performance. https://escholarship.org/uc/item/3k89n5b7\#main

Elkington, J. (1997). Cannibals with Forks: The Triple Bottom Line of 21st Century Business. Capstone Publishing.

Ennis, C., Kottwitz, J., Lin, S. X., \& Markusson, N. (2012). Exploring the Relationships between Carbon Disclosure and Performance in FTSE 350 Companie.

Fitria, S., \& Hartanti, D. (2010). Islam dan Tanggung Jawab Sosial: Studi Perbandingan Pengungkapan berdasarkan Global Reporting Initiative Indeks dan Islamic Social Reporting Indeks. Simposium Nasional Akuntansi XIII, 1-33.

Gallego-Alvarez, I., Sagura, L., \& Martínez-Ferrero, J. (2015). Carbon Emission Reduction: 
The Impact on The Financial and Operational Performance of International Companies. Journal of Cleaner Production, 103(15 September), 149-159. https://doi.org/10.1016/j.jclepro.2014.08.047

Gray, R., Kouhy, R., \& Lavers, S. (1995). Corporate Social and Environmental Reporting: A Review of The Literature and A Longitudinal Study of UK Disclosure. Accounting, Auditing \& Accountability Journal, 8(2), 47-77. https://doi.org/10.1108/09513579510146996

Griffin, P. A., \& Sun, E. (2013). Going Green: Market Reaction to CSR Newswire Releases. Journal of Accounting and Public Policy, 32(2). https://doi.org/10.2139/SSRN.1995132

Hadi, M. S. (2013). 25 Perusahaan Ini Masuk Kategori Pro-Lingkungan. TEMPO.CO. https://tekno.tempo.co/read/501662/25-perusahaan-ini-masuk-kategori-prolingkungan/full\&view=ok

Hanifa, R. (2002). Social Reporting Disclosure: An Islamic Perspective. Indonesia Management \& Accounting Research, 1(2), 128-146. https://kitlvdocs.library.leiden.edu/open/345610423.pdf

Höbarth, L. L. (2006). Modeling The Relationship between Financial Indicators and Company Performance: An Empirical Study for US-listed Companies [Vienna University of Economics and Business]. https://epub.wu.ac.at/1870/

Irwhantoko, I., \& Basuki, B. (2016). Carbon Emission Disclosure: Studi pada Perusahaan Manufaktur Indonesia. Jurnal Akuntansi Dan Keuangan, 18(2), 92-104. https://doi.org/10.9744/jak.18.2.92-104

Juniarti, J., \& Sentosa, A. A. (2009). Pengaruh Good Corporate Governance, Voluntary Disclosure terhadap Biaya Hutang (Costs of Debt). Jurnal Akuntansi Dan Keuangan, 11(2), 88-100.

https://jurnalakuntansi.petra.ac.id/index.php/aku/article/view/17933

Kelvin, C., Daromes, F. E., \& Ng, S. (2017). Pengungkapan Emisi Karbon sebagai Mekanisme Peningkatan Kinerja untuk Menciptakan Nilai Perusahaan. Dinamika Akuntansi, Keuangan Dan Perbankan, 6(1), 1-18. https://www.unisbank.ac.id/ojs/index.php/fe9/article/view/5948/0

Othman, R., Thani, A. M., \& Ghani, E. K. (2009). Determinants of Islamic Social Reporting Among Top Shariah-Approved Companies in Bursa Malaysia. Research Journal of International Studies, 12, 1-20.

https://www.researchgate.net/publication/228783690_Determinants_of_Islamic _Social_Reporting_Among_Top_Shari\%27a-

Approved_Companies_in_Bursa_Malaysia

Peng, J., Sun, J., \& Luo, R. (2014). Corporate Voluntary Carbon Information Disclosure: Evidence from China's Listed Companies. The World Economy, 38(1), 91-109. https://doi.org/10.1111/twec.12187

Purwanto, W. W., Nugroho, Y. S., Dalimi, R., Soepardjo, A. H., Wahid, A., Supramono, D., Herminna, D., \& Adlina, T. A. (2006). Indonesia Energy Outlook and Statistics 2006 (Pengkajian Energi Universitas Indonesia (ed.)). Pengkajian Energi Universitas 
Indonesia. https://doi.org/10.13140/RG.2.1.1798.4080

Rahma, A. (2010). Pengaruh Environmental Performance terhadap Financial Performance Perusahaan berdasarkan Peringkat Penghargaan PROPER. Universitas Negeri Semarang.

Saka, C., \& Oshika, T. (2014). Disclosure Effects, Carbon Emissions and Corporate Value. Sustainability Accounting, Management, and Policy Journal, 5(1), 22-45. https://doi.org/10.1108/SAMPJ-09-2012-0030

United States Environmental Protection Agency. (2018). Global Emissions by Gas. https://www.epa.gov/ghgemissions/global-greenhouse-gas-emissions-data Zafarina, R. S. (2016). Pengaruh Environmental Performance terhadap Financial Performance pada Perusahaan Manufaktur yang Terdaftar pada BEI Periode 2013. STIE Perbanas. 